Original Research paper

\title{
New Golden Red Sodium Calcium Silicate Glasses
}

\author{
${ }^{1}$ Wang Cheng-Yu, ${ }^{2}$ Wun Nuan-Xin, ${ }^{3} \mathrm{Ge} \mathrm{Yi},{ }^{4}$ Tang Hua-Juan and ${ }^{5}$ Wang Paul W \\ ${ }^{1}$ School of Textile and Materials Engineering, Dalian Polytechnic University, Dalian, 116034, China \\ ${ }^{2}$ Dandong Glass Products Factory, Dandong, 118001, China \\ ${ }^{3}$ Liaoyang Twin Craft Factory, Liaoyang, 110000, China \\ ${ }^{4}$ Dalian Casamotion Art Glass Co., Ltd Dalian 1103083, China \\ ${ }^{5}$ Department of Physics, Bradley University, Peoria, IL 61625, USA
}

Article history

Received: 23-10-2018

Revised: 08-01-2019

Accepted: 09-02-2019

Corresponding Author:

Wang Paul W,

Department of Physics, Bradley

University, Peoria IL, USA

Email: pwang $@$ bradley.edu

\begin{abstract}
Traditional golden red glasses were based on $\mathrm{K}_{2} \mathrm{O}-\mathrm{PbO}-\mathrm{SiO}_{2}$ composition system. In this paper, we reported new golden red glasses based on $\mathrm{Na}_{2} \mathrm{O}-\mathrm{CaO}-\mathrm{SiO}_{2}$ system without $\mathrm{SnO}_{2}$ and $\mathrm{PbO}$ in them. By using a spectrophotometer and chromamter color difference meter, it was found that the new glasses had similar optical properties to the traditional ones. The diameter of the gold particles in new glasses is around $40 \mathrm{~nm}$ determined by scanning electron microscope. The surface plasmon resonance created by the absorption of visible light emits golden red color. The benefits of using new golden red sodium calcium silicate glasses are the reductions of gold amount, cost and lead pollution to the environment.
\end{abstract}

Keywords: New Soda Lime Based Golden Red Glasses, Low Gold Content, Without Lead and Tin, No Lead Pollution

\section{Introduction}

Tammannn and Schrader (1929) studied systematically how gold composition in glasses modified the colors of glasses in 1920s. First, gold ions were introduced in the glass, gold ions then reduced to atomic gold, through the nucleation process the gold crystals grew to a certain size. When visible light is incident on the gold particles a group of electrons resonantly oscillates on the surfaces of gold particles at a certain frequency, i.e. a certain incident wavelength of light was absorbed by electrons in the gold particles, then those oscillating electrons so called surface plasmons (de Aberasturi et al., 2015), emitted light at the same frequency of the color. Tammannn and Schrader (1929) found out the colors of the glasses were correlated to the sizes of the gold particles. Golden red glasses showed rosy red so they were also called golden red jams.

Usually $\mathrm{K}_{2} \mathrm{O}-\mathrm{PbO}-\mathrm{SiO}_{2}$ system was used for the basic composition of the golden red glasses (Weyl, 1999; Rooksby, 1932; Scholes, 1974; Morey, 1954). Compared $\mathrm{K}_{2} \mathrm{O}-\mathrm{PbO}-\mathrm{SiO}_{2}$ system to $\mathrm{Na}_{2} \mathrm{O}-\mathrm{CaO}-\mathrm{SiO}_{2}$ system glasses, gold has a higher solubility in $\mathrm{PbO}$ contained glasses. Gold was also easier to be nucleated during heating in $\mathrm{PbO}$ contained golden red $\mathrm{K}_{2} \mathrm{O}-\mathrm{PbO}-\mathrm{SiO}_{2}$ system glasses. Volf (1984) reported red color was obtained by adding only 0.01 to $0.02 \%$ gold in glasses. The gold content in high lead contained golden red glasses could reach $0.1 \%$ reported by Rooksby (1932) and Morey (1954). Volf (1984) found that golden red color could be seen in $\mathrm{Na}_{2} \mathrm{O}-\mathrm{CaO}-\mathrm{SiO}_{2}$ based glasses with only $0.02-0.06 \%$ gold in them. However, in order to increase the solubility of gold in glasses at low temperature and to prevent the precipitation of gold when viscosity of glasses is low, protect agent of 0.5$1.0 \% \mathrm{SnO}_{2}$ had to add in $\mathrm{Na}_{2} \mathrm{O}-\mathrm{CaO}-\mathrm{SiO}_{2}$ glasses. Volf (1984) reported that the amount of $\mathrm{SnO}_{2}$ was twice of that of gold in his $\mathrm{Na}_{2} \mathrm{O}-\mathrm{CaO}-\mathrm{SiO}_{2}$ glasses.

There are advantages to use $\mathrm{K}_{2} \mathrm{O}-\mathrm{PbO}-\mathrm{SiO}_{2}$ as base glass system for golden red glasses; however, lead is not only poisonous to humans but also pollutes the environment. Johnson (1997) reported that lead will be banned in glasses in Europe, hence, it is a must to find an alternative way to manufacture golden red glasses.

In this paper, $\mathrm{Na}_{2} \mathrm{O}-\mathrm{CaO}-\mathrm{SiO}_{2}$ was used as the basic golden red glass system. Less gold amount, no $\mathrm{SnO}_{2}$ and no $\mathrm{PbO}$ were used in our new golden red glasses. It was found that the second time heat treatment to enhance the color is not necessary compared to the traditional fabrication of $\mathrm{K}_{2} \mathrm{O}-\mathrm{PbO}-\mathrm{SiO}_{2}$ based golden red glasses. The properties and fabrication of the new golden red glasses were studied and reported.

\section{Experiments}

The advantages of using $\mathrm{Na}_{2} \mathrm{O}-\mathrm{CaO}-\mathrm{SiO}_{2}$ as a base glass system are it easily melts due to high alkali concentration and the hardening speed is slow due to low $\mathrm{CaO}$ concentration. Therefore, the glass system is suitable to fabricate complex shaped products by 
blowing or pressing due to its broad range of glass formation temperature. In Table 1, the compositions of new and traditional golden red glass systems were listed in mass percentage. According to the composition, the material ratios were calculated and listed in Table 2.

The sample preparation started with $99.9 \%$ pure gold nugget dissolving in aqua regia to obtain $\mathrm{AuCl}_{3}$ solution, then the solution was mixed with quartz sand. Since the amount of gold is so small, a second mixture was done by adding the solution with quartz sand to other raw materials in order to have more uniform distribution of gold in the mixture. Usually $\mathrm{As}_{2} \mathrm{O}_{3}$ is used in lead glass as refining agent, but compound of $\mathrm{As}_{2} \mathrm{O}_{3}$ and $\mathrm{Sb}_{2} \mathrm{O}_{3}$ is used in sodium calcium silicate glasses as a refining agent. Compound refining agent containing $\mathrm{As}_{2} \mathrm{O}_{3}$ and $\mathrm{Sb}_{2} \mathrm{O}_{3}$ also enhances the solubility of gold in sodium calcium silicate glasses.
Sample materials were uniformly mixed according to the composition ratios listed in Table 2, put into the ceramic crucible, then heat was applied until it melted. Later mixed raw materials were added at temperature between 1450 and $1470^{\circ} \mathrm{C}$, the refining agent was then added at temperature between 1550 and $1580^{\circ} \mathrm{C}$, sample then cooled down and finally the glasses were formed at temperature between 1150 and $1200^{\circ} \mathrm{C}$. The observed heating temperature as a function of time during the sample heat treatment was shown in Fig. 1. It is clear seen in Fig. 1 that once the raw materials were added the recorded temperature dropped. The shape of the final glass products could be formed in many different ways such as blowing, pressing, molding in transparent container then blowing, or forming by an non-container mold off-hand process.

Table 1: The compositions of traditional and new golden red glasses in mass percentage

\begin{tabular}{lllllllllll}
\hline & $\mathrm{SiO}_{2}$ & $\mathrm{~B}_{2} \mathrm{O}_{3}$ & $\mathrm{CaO}$ & $\mathrm{Pb}_{3} \mathrm{O}_{4}$ & $\mathrm{BaO}$ & $\mathrm{Na}_{2} \mathrm{O}$ & $\mathrm{K}_{2} \mathrm{O}$ & $\mathrm{SnO}_{2}$ & $\mathrm{~F}$ & $\mathrm{Au}$ \\
\hline $\begin{array}{l}\text { Traditional golden red glasses } \\
\mathrm{K}_{2} \mathrm{O}-\mathrm{PbO}-\mathrm{SiO}_{2} \text { base system }\end{array}$ & 56.22 & 2.58 & 0 & 25.20 & 2.41 & 3.11 & 9.22 & 1.20 & 0 & 0.06 \\
$\begin{array}{l}\mathrm{New} \text { golden red glasses } \\
\mathrm{Na}_{2} \mathrm{O}-\mathrm{CaO}-\mathrm{SiO}_{2} \text { base system }\end{array}$ & 76.92 & 1.12 & 3.05 & 0 & 0 & 18.56 & 0 & 0 & 0.34 & 0.01 \\
\hline
\end{tabular}

Table 2: The raw material ratios used in traditional and new golden red glasses

\begin{tabular}{|c|c|c|c|c|c|c|c|c|c|c|c|c|c|}
\hline & $\begin{array}{l}\text { Quartz } \\
\text { sand }\end{array}$ & $\mathrm{H}_{3} \mathrm{BO}_{3}$ & $\mathrm{CaCO}_{3}$ & $\mathrm{~Pb}_{3} \mathrm{O}_{4}$ & $\mathrm{BaCO}_{3}$ & $\mathrm{Na}_{2} \mathrm{CO}_{3}$ & $\mathrm{NaNO}_{3}$ & $\mathrm{~K}_{2} \mathrm{CO}_{3}$ & $\mathrm{SnO}_{2}$ & $\mathrm{CaF}_{2}$ & $\mathrm{Au}$ & $\mathrm{Sb}_{2} \mathrm{O}_{3}$ & $\begin{array}{l}\text { refining } \\
\text { agent }\end{array}$ \\
\hline $\begin{array}{l}\text { Traditional golden } \\
\text { red glasses } \\
\mathrm{K}_{2} \mathrm{O}-\mathrm{PbO}-\mathrm{SiO}_{2} \\
\text { base system }\end{array}$ & 100 & 8.9 & 0 & 53.18 & 7.1 & 0 & 0 & 8.09 & 2.31 & 0 & 0.06 & 2.31 & 0 \\
\hline $\begin{array}{l}\text { New golden } \\
\text { red glasses } \\
\mathrm{Na}_{2} \mathrm{O}-\mathrm{CaO}-\mathrm{SiO}_{2} \\
\text { base system }\end{array}$ & 100 & 3.5 & 5 & 0 & 0 & 38 & 3.5 & 0 & 0 & 0.54 & 0.03 & 0 & 0.75 \\
\hline
\end{tabular}

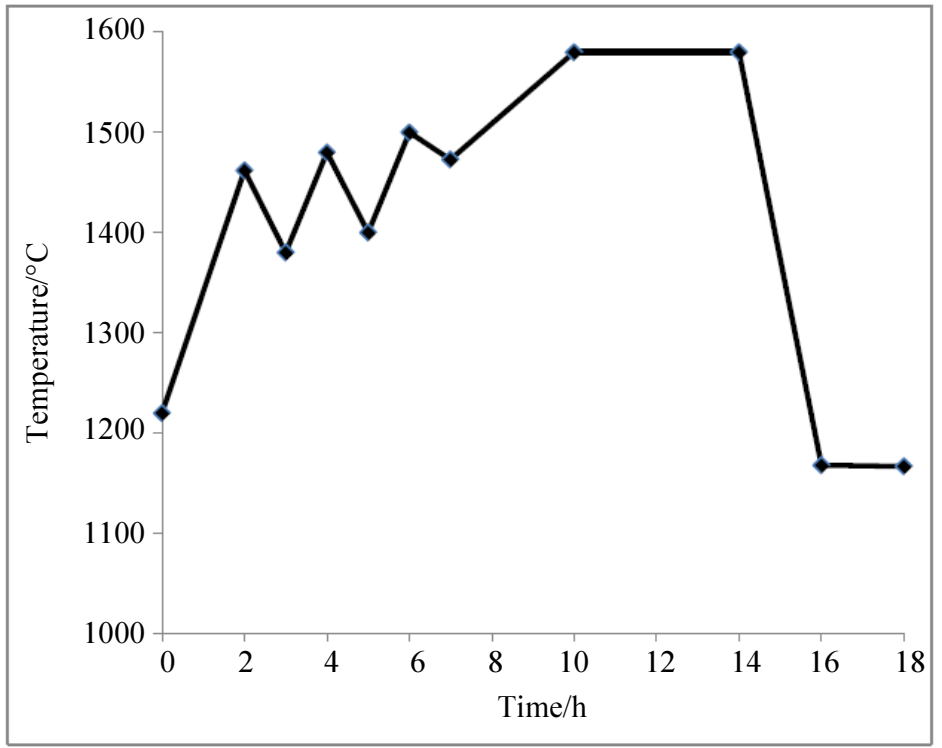

Fig. 1: The sample process temperature as a function of time curve 
The gold red color was obtained at the glass forming temperature in new golden red glasses. The annealing of the new glasses was performed at temperature between 530 and $540^{\circ} \mathrm{C}$. It was found that the golden red color was already obtained at the glass forming temperature. However, the golden red color in traditional $\mathrm{K}_{2} \mathrm{O}-\mathrm{PbO}-$ $\mathrm{SiO}_{2}$ base glasses could only be obtained by two heat treatments, i.e., annealing and later heating treatment; one is at temperature between 530 and $540^{\circ} \mathrm{C}$ and the other is at temperature between 570 and $600^{\circ} \mathrm{C}$. The golden red color appeared only after the second heat treatment, i.e., so called striking.

Annealed new golden red glasses were investigated (1) by using JSM 6460LV Scanning Electron Microscope to determine the size of the gold nanocrystal, (2) by using METASH UL-8000 spectrophotometer to study the transmission curve, (3) by using Data Color $7000 \mathrm{~A}$ chromameter to measure the coordination in color purity chromaticity diagram, main wavelength, color purity and total transmission and (4) finally by using ISO 7991:1987 method to determine the average thermal expansion coefficient of new golden red glasses.

\section{Results and Discussion}

Melts of golden red sodium calcium silicate materials were pressed in glass plates then polished to $2 \mathrm{~mm}$ thick pieces after annealing. The typical transmittance curve of the sample measured by the optical spectrophotometer was shown in Fig. 2 in which $a$ was obtained from new golden red glasses and $b$ was from $\mathrm{PbO}$ content traditional golden red glasses.

The main absorption peak of new golden red glasses located at ca. $540 \mathrm{~nm}$ was narrower. However, in the traditional glasses the main peak is around $580 \mathrm{~nm}$ and broader which was similar to the properties of $\mathrm{SnO}_{2}$ contained $\mathrm{Na}_{2} \mathrm{O}-\mathrm{CaO}-\mathrm{SiO}_{2}$ glass reported by Volf (1984) as shown in Fig. 3. The top row letters in Fig. 3 indicate colors: $\mathrm{v}$ for violet, $\mathrm{b}$ for blue, $\mathrm{g}$ for green, $\mathrm{y}$ for yellow, or for orange and $r$ for red.

By using the color difference meter and standard light source $\mathrm{C}$, the positions of new and traditional golden red glasses in ICE chromaticity diagram were shown in Fig. 4 in which $\mathrm{s}$ represented new and $\mathrm{p}$ was for traditional glasses. Two coordinates were very close and almost at the same position in the ICE chromaticity diagram. New glasses had $20.31 \%$ color purity, $34.28 \%$ total transmittance and the main wavelength was 640 $\mathrm{nm}$. The traditional glasses had $21.50 \%$ color purity, $38.45 \%$ total transmittance and the main wavelength is longer than $640 \mathrm{~nm}$. Color purity and transmittance were higher in traditional than in new glasses.

Other properties such as density, index of refraction, linear thermal expansion coefficient and softening temperature of new and traditional glasses were listed in Table 3. Since traditional golden red glass contained more $\mathrm{PbO}(25.2 \%)$ hence its density and index of refraction were higher but their linear thermal expansion coefficient and softening temperature were lower than those in new glass.

Table 3: The property comparison between new and traditional golden red glasses

\begin{tabular}{llc}
\hline & $\mathrm{New}$ golden red glasses & Traditional new golden red glasses \\
Property & $\mathrm{Na}_{2} \mathrm{O}-\mathrm{CaO}-\mathrm{SiO}_{2}$ base system & $\mathrm{K}_{2} \mathrm{O}-\mathrm{PbO}-\mathrm{SiO}_{2}$ base system \\
\hline Density $\left(\mathrm{g} / \mathrm{cm}^{3}\right)$ & 2.52 & 2.980 \\
Index of refraction & 1.50 & 1.562 \\
Linear thermal expansion coefficient $\left(\times 10^{-7} /{ }^{\circ} \mathrm{C}\right)\left(20-250^{\circ} \mathrm{C}\right)$ & 105 & 102.000 \\
Softening temperature $\left({ }^{\circ} \mathrm{C}\right)$ & 695 & 678.000 \\
\hline
\end{tabular}

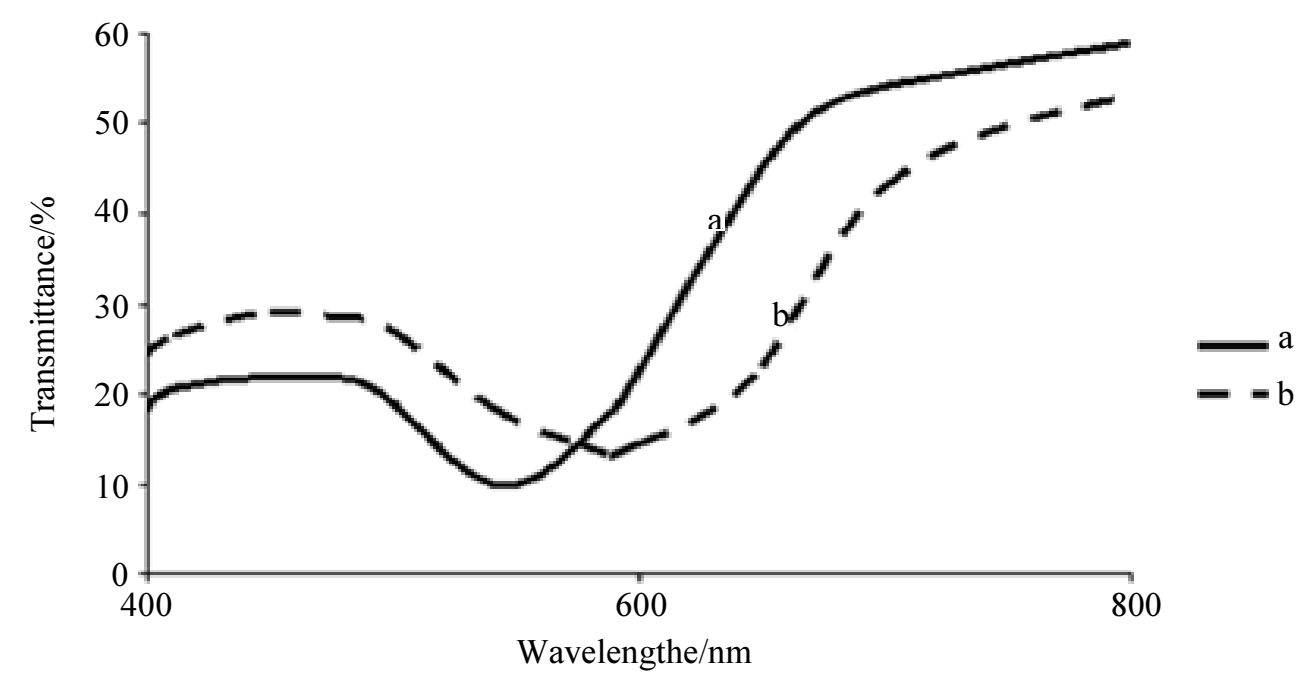

Fig. 2: Transmission spectra of golden red glass in which (a) new golden red glass and (b) PbO content golden red glass 


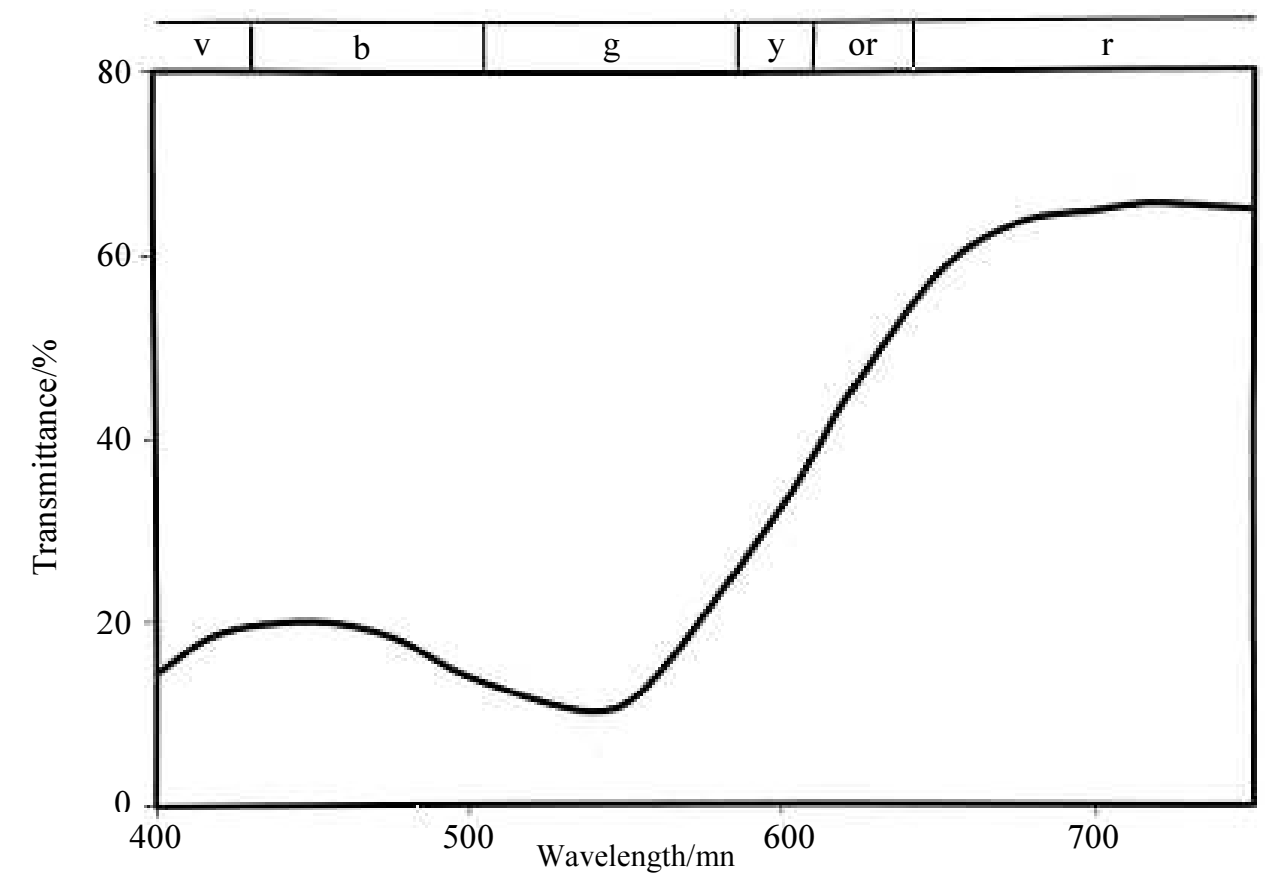

Fig. 3: Curves of spectral transmission of $\mathrm{Na}_{2} \mathrm{O} \cdot \mathrm{CaO} 6 \mathrm{SiO}_{2}$ glass colored by addition $\mathrm{Au}$

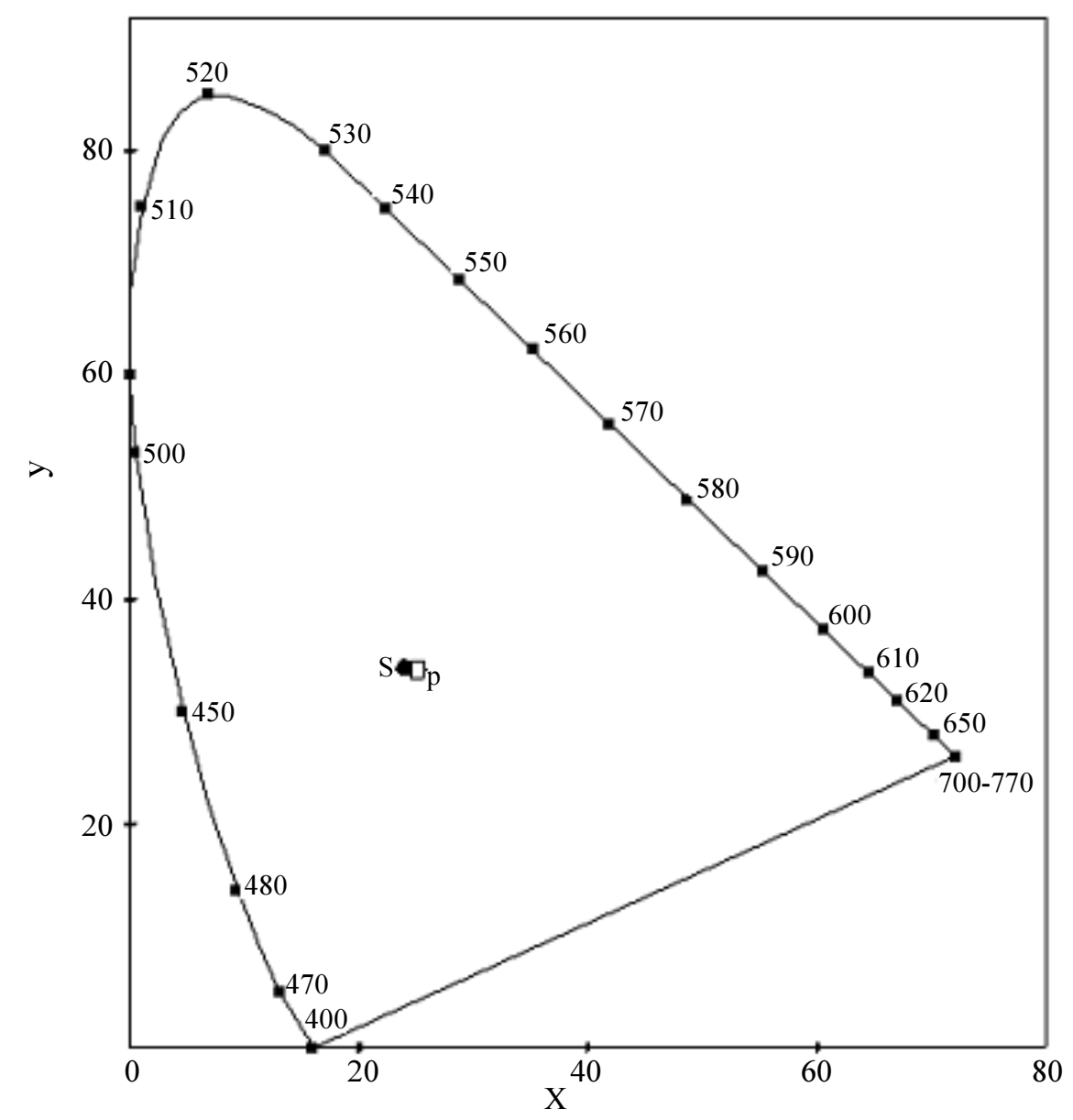

Fig. 4: Sample position in CIE chromaticity diagram 


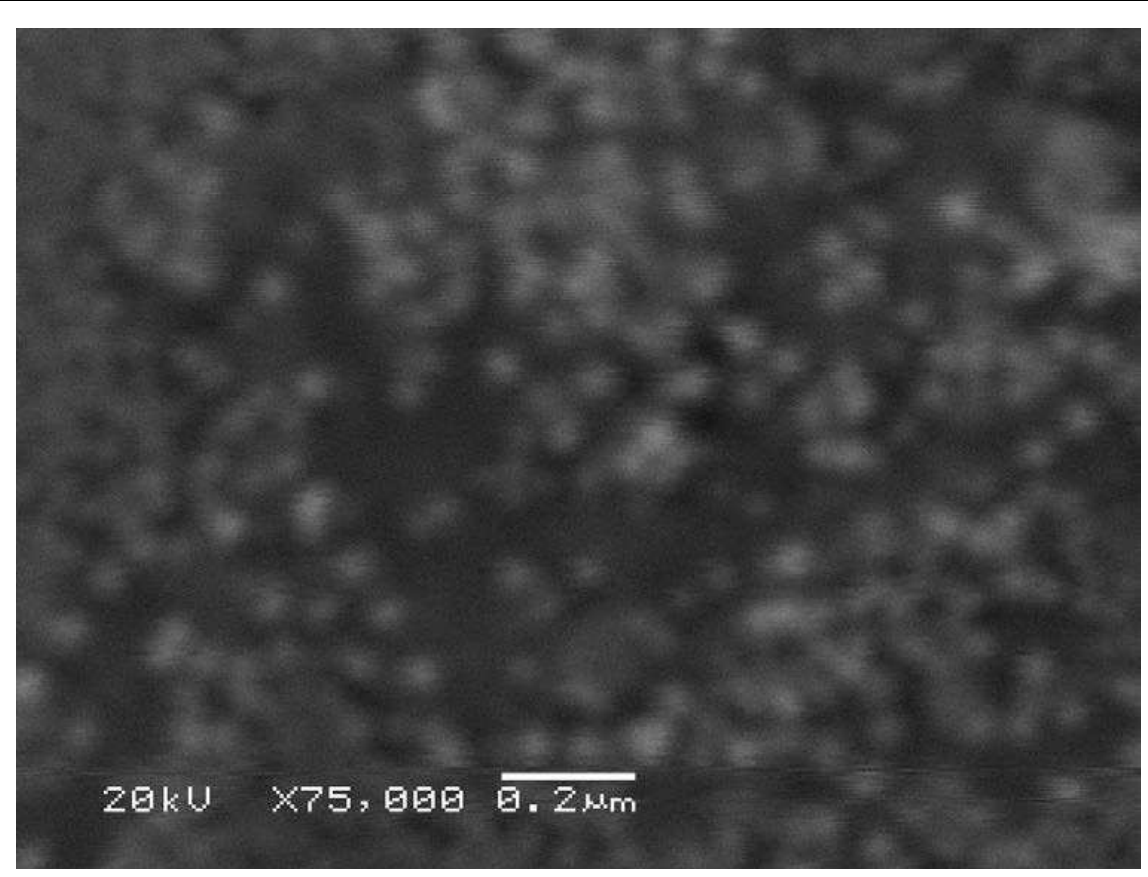

Fig. 5: Sizes and shapes of gold nanoparticles examined by SEM

The mass of gold content in the raw materials of new glass is about $83 \%$ less than in the old glass as shown in Table 1. Consequently, the cost reduction of fabrication new glasses is about $83 \%$ less than traditional ones just by considering the reduction of gold used in the new glasses. Because of the low gold content, the gold still dissolved in the glass without adding $\mathrm{SnO}_{2}$. However, $\mathrm{CaF}_{2}$ did add into the raw materials to initiate gold nucleation process and to enhance the formation of the gold nanocrystals. The size of the nanoparticles was about $40 \mathrm{~nm}$ determined by the Scanning Electron Microscope (SEM). The sizes and shapes of the nanoparticles examined by SEM were shown in Fig. 5 .

From the Tammann's report (Tammannn and Schrader, 1929), color of the gold particle is related to its size; colorless for $5 \mathrm{~nm}$ or less gold particles, pink for 10 $\mathrm{nm}$, purple red for $10 \sim 20 \mathrm{~nm}$ and dark purple red for the $20 \sim 50 \mathrm{~nm}$ gold particles. Our result, $\sim 40 \mathrm{~nm}$ size of gold nanoparticles in new glasses was dark purple by vision which is consistent to Tammann's results (Tammannn and Schrader, 1929).

\section{Conclusion}

New $\mathrm{Na}_{2} \mathrm{O}-\mathrm{CaO}-\mathrm{SiO}_{2}$ based golden red glasses without $\mathrm{PbO}$ and $\mathrm{SnO}_{2}$ and containing only $0.01 \%$ gold in mass percentage were fabricated and reported. Compared to traditional golden red glasses, the mass of gold in new glasses was $83 \%$ reduced. None $\mathrm{SnO}_{2}$ and none $\mathrm{PbO}$ were used in new glasses hence the impact of the environmental pollution was greatly reduced. Moreover, steady golden red color in the new glass could be obtained only by annealing once compared to both annealing and heating processes in traditional glass in order to striking the golden red color. With the advantage of reduction of gold amount, significantly minimizing the environmental pollution impact and one step of the thermal process to obtain the golden red color, the new glasses are promising future golden red glasses.

\section{Acknowledgement}

Wang P.W. and Wang C.Y. acknowledge the support of this research from Bradley University and Dalian Polytechnic University.

\section{Funding Information}

The authors acknowledge the funding received from the institutes each author works at.

\section{Author's Contributions}

Wang Cheng-Yu: Was the project leader of this research, designed the experimental scheme, guided further experiments based on the results and discussion.

Wun Nuan-Xin: Performed glass composition and batch experiments.

Ge Yi: Prepared materials and performed glass melting and forming experiments.

Tang Hua-Juan: Determined glass properties, data collection and analyses by various techniques.

Wang Paul W: Contributed mostly in discussion and publication of this manuscript. 


\section{Ethics}

Authors ensured originality and quality of this collaborative research. Each author's significant contribution was evaluated and the names of authors were ordered accordingly.

\section{References}

de Aberasturi, D.J., A.B. Serrano-Montes and L.M. LizMarzán 2015. Modern applications of plasmonic nanoparticles: From energy to health Adv. Opt. Mater., 3: 602-17.
Johnson, B., 1997. Glasrcknik Tidskrift, 529: 1-5.

Morey, G.W., 1954. The Properties of Glasses, 2nd Edn., Reinhold, The University of Michigan, pp: 591.

Rooksby, H.P., 1932. J. Soc. Glass. Tech., 16: 171.

Scholes, S.R., 1974. Modern Glass Practice, 7th Edn., Cahness Publishing Co. pp: 321.

Tammann, G. and H. Schrader, 1929. Ztschr Anorg. Allg. Chemie 184: 293.

Volf, M.B., 1984. Chemical Approach to Glass, Published by Elsevier, pp: 494.

Weyl, W.A., 1999. Coloured Glasses. Published by Society of Glass Tech. 